American Journal of Applied Sciences 7 (12): 1562-1568, 2010

ISSN 1546-9239

(C) 2010 Science Publications

\title{
Rational Mix Design Approach for High Strength Concrete Using Sand with very High Fineness Modulus
}

\author{
${ }^{1}$ Kwan Wai Hoe and ${ }^{2}$ Mahyuddin Ramli \\ ${ }^{1}$ Department of Building Technology, School of Housing, Building and Planning \\ ${ }^{2}$ University Sains Malaysia, Pulau Pinang, Malaysia
}

\begin{abstract}
Problem statement: Production of concrete is always deal with inconsistency. Sources of variation like materials from different geographical basis, mix design method, fineness of aggregates and so on will attribute to different level of achievement of the concrete. Even though researcher had verified that higher fineness modulus of sand would yield better performance for the concrete, but so far there have been scarce amount of paper reported on the mix design method adopting high fineness modulus of sand. Approach: This study discussed the revolution of design mix proportion towards achieving high strength with considerably cement content using local availably constituent materials. A total of 15 mixes was casted till to the high strength at more than $65 \mathrm{MPa}$ was achieved. The compressive strength and workability of each mixes were presented. The method of mixture proportioning was begun with British Department Of Environment (DOE) method. Then, rational design method of achieving high strength concrete was developed. Results: At the end of experimental program, it was found that DOE method was not suitable to apply in designing high strength concrete. $12 \%$ was the optimum level of replacement of the total binder content by silica fume. Further increase of total binder content without adjustment to the amount of aggregate content has decreased the strength achievement of the concrete. Very coarse fine aggregate with fineness modulus 3.98 increased the compressive strength of the concrete in large extent. The increased of superplasticiser from $2.0 \%$ to $2.5 \%$ has decreased the compressive strength of the concrete. Conclusion: The rational mix design approach was developed. A Grade 70 concrete can be produced with moderate level of cement content by this approach.
\end{abstract}

Key words: High Strength Concrete (HSC), super plasticizer, fineness modulus, Department Of Environment (DOE), rational mix design, normal concrete, superplasticiser dosage, constituent materials, silica fume, cementations amount

\section{INTRODUCTION}

The application of High Strength Concrete (HSC) is gaining popularity in the built environment. Since 1960 s, when the ready mix high strength concrete is readily available, the trend of using rigid steel structure in high rise construction has slowly shifted to reinforced concrete structure. Today, this reinforced concrete structure using HSC has almost completely superseded the steel structures in both high rise constructions and other civil engineering works. The concrete possess high compressive strength comes with lots of valuable properties, such as high abrasion resistance, stiffness, low permeability, higher durability, higher early strength gain and lower cost per unit load. (Caldarone, 2009; Naidu, 1995; Early High Strength Concrete Advantages and Challenges 2008-2009.
To attain high strength, specific mix proportioning method and the constituent materials are strictly selected as the requirements are gaining stringent (Caldarone, 2009). Different methods of mix proportioning arises different amount of composite materials proportions even though targeting the similar strength. But one of the confirmed facts is that the design mix of HSC must apply a specific proportioning method. Up to $50 \%$ saving in cement consumption can attain by specific proportioning method for the equivalent 28 days compressive strength rather than conventional designing method for normal concrete. Consequently, a great reduction in energy generated in the production cement and saving in cost of production is enabled by it (Alves et al., 2004).

The incorporation of pozzolonic materials is presently an all round method to attain high strength while maintaining lower cement amount and partially reduced the problems of thermal shrinkage, self-

Corresponding Author: Mahyuddin Ramli, University Sains Malaysia, Pulau Pinang, Malaysia 
desiccation and Silica fume, also known as microsilica, is one of the promising by-products from production of silicon and ferrorsilicon act as the key opening for the gateway to achieve high strength, both early and later age. It contributes both pozzolonic and filler effect to the concrete, but more dominantly in filling effects due to its extremely fine particle size. As a result, it drastically increases the water demand of the mixture but it can be overcome by incorporating high range water reducing admixture like superplasticiser (Caldarone, 2009; Neville, 1995; Khatri and Sirivivatnanon, 1995; Ravichandran et al., 2009; Roshan et al., 2010) The finely divided particles reacts aggressively with calcium hydroxide when added to the fresh concrete and forms calcium silicate hydrate, which enhance the resistivity of concrete towards chemical attacks and compressive strength (Caldarone, 2009). The filler effect is resulted by the extremely fine $(<1$ micrometer) particles. It refines the microstructures by better particles packing in the interfacial zone and hence creates smaller pores which also enhance both durability and strength of HSC.

\section{MATERIALS AND MATHODS}

Ordinary Portland cement and condensed silica fume were used throughout the whole experimental program. The specifications of both cementitious compounds are shown in Table 1. The original river sand ( specific gravity $=2.51$; fineness modulus $=2.94$ ) used in the A series mixes in this experiment was stored in the laboratory. The particle distribution curves are shown in Fig 1. Crushed granite (specific gravity = 2.70) of nominal maximum size $19 \mathrm{~mm}$, was used as coarse aggregate. The fine aggregate was then modified, passed through $4.75 \mathrm{~mm}$ sieve with fineness modulus of 3.98 was used in the B, C and D series of mixes. The particle size distribution curves of modified fine aggregate are shown in Fig. 2. Conplast SP 1000, a chloride free superplasticizing admixture based on sulphonated naphthalene polymers which complying BS 5075 was used as super plasticizer throughout the experimental program.

Table 1: Chemical composition of ordinary portland cement and

\begin{tabular}{|c|c|c|}
\hline \multicolumn{3}{|c|}{ Ordinary portland } \\
\hline Constituent & $\begin{array}{l}\text { Cement } \\
\text { (\%) by weight }\end{array}$ & $\begin{array}{l}\text { Silica fume } \\
\text { (\%) by weight }\end{array}$ \\
\hline Lime $(\mathrm{CaO})$ & 64.64 & $1.0 \%(\max )$ \\
\hline Silica (SiO2) & 21.28 & $90 \%(\max )$ \\
\hline Alumina( $\mathrm{Al} 2 \mathrm{O} 3$ ) & 5.60 & $1.2 \%(\max )$ \\
\hline Iron Oxide( $\mathrm{Fe} 2 \mathrm{O} 3)$ & 3.36 & $2.0 \%(\max )$ \\
\hline Magnesia(MgO) & 2.06 & $0.6 \%(\max )$ \\
\hline Sulphur Trioxode (SO3) & 2.14 & $0.5 \%(\max )$ \\
\hline $\mathrm{N} 2 \mathrm{O}$ & 0.05 & $0.8 \%(\max )$ \\
\hline Loss of Ignition & 0.64 & $6 \%(\max )$ \\
\hline Lime saturation factor & 0.92 & ----- \\
\hline C3S & 52.82 & ---- \\
\hline $\begin{array}{l}\text { C2S } \\
\text { C3A }\end{array}$ & 21.45 & ---- \\
\hline $\begin{array}{l}\text { C3A } \\
\text { C4AF }\end{array}$ & $\begin{array}{l}9.16 \\
10.2\end{array}$ & --- \\
\hline
\end{tabular}

Experimental program: 6 cubes with dimension of $100 \times 100 \times 100 \mathrm{~mm}$ casted for each mix proportions to determine their compressive strength according to BS EN 12390-3, 2009 while the slump test is done in accordance with BS EN 12350-2, 2009. The specimens were tested at the aged of 7 days and 28 days. All of the specimens were allowed to cure in water at temperature $23 \pm 2{ }^{\circ} \mathrm{C}$ until the age of testing. A series of was designed to have compressive strength of $60 \mathrm{MPa}$ at 28 days using DOE method. About $8-10 \%$ of silica fume was added to the cementations compound using $1 \%$ of superplasicizer to control the workability. In B series mixes, the concrete was designed by adopting the mix proportion proposed by Neville (1995). In C series mixes, the total cementations material was increased to $510 \mathrm{~kg} / \mathrm{m}^{3}$ while the water binder ratio, aggregate contents, superplasticiser dosage was maintained as in $\mathrm{B}$ series. The D series mixes was designed according to ACI method (2007) and Metha / Aitcin Method (1990) with some rational modifications and the design mix process was further elaborated.

Mix design procedure: Compressive strength was targeted to have $65 \mathrm{MPa}$ and Table 2 was used to establish standard deviation $(\mathrm{S})$, the required average strength would be:

$$
\begin{aligned}
\mathbf{f}^{\prime} \mathbf{c r} & =1.10 \mathrm{fc}+4.8 \\
& =1.10(65)+4.8 \\
& =76.3 \mathrm{MPa}
\end{aligned}
$$

Estimate water content and air content: Incorporation super plasticizer by $2 \%$ of total binder weight into the mix would reduce the water demand. Hence, the water content estimated from Table 3 would be reduced by $10 \%$.

With that consideration, the following criteria had been used:

- Nominal maximum size of aggregate, $19 \mathrm{~mm}$

- $\quad$ Fineness modulus of sand, 3.98

- Target slump, 25-50 mm,

- Non-Air entrained concrete,

- The water content estimated from Table 3 is 190 $\mathrm{kg}$, less $10 \%$ (19kg)

Table 2: Required average compressive strength when data are not available to establish a standard deviation (American Concrete Institute, 2007a; ACI 318-08, 2008)

\begin{tabular}{ll}
\hline $\begin{array}{l}\text { Specified } \\
\text { compressive strength }\end{array}$ & $\begin{array}{l}\text { Requiredaverage } \\
\text { compressive strength }\end{array}$ \\
f'c, psi & f'cr, psi \\
\hline Less than 3000 & fc' +1000 \\
$3000-5000$ & fc' +1200 \\
Over 5000 & $1.10 \mathrm{fc}^{\prime}+700$ \\
\hline
\end{tabular}


Am. J. Applied Sci., 7 (12): 1562-1568, 2010

Table 3: Selecting proportions for normal, heavyweight and mass concrete (American Concrete Institute, 2007b; ACI 211.1-91)

Approximate mixing water and air content requirements for different slumps and nominal maximum sizes of aggregates (SI), non-air entrained concrete

\begin{tabular}{|c|c|c|c|c|c|}
\hline & & \multicolumn{4}{|c|}{ Water, $\mathrm{kg} \mathrm{cum}^{-1}$, for indicated nominal maximum sizes of aggregates } \\
\hline Slump, mm & 9.5 & $\begin{array}{l}12.5 \\
100\end{array}$ & 19.0 & 25.0 & $\begin{array}{l}37.5 \\
166\end{array}$ \\
\hline $\begin{array}{l}25-50 \\
75-100\end{array}$ & 228 & 299 & 190 & 179 & 186 \\
\hline $150-175$ & 243 & 228 & 216 & 202 & 190 \\
\hline $\begin{array}{l}\text { Approx. amount of } \\
\text { entrapped air, (\%) }\end{array}$ & 3.0 & 2.5 & 2.0 & 1.5 & 1.0 \\
\hline
\end{tabular}

Table 4: Example constituent material combinations for pastes of varying W/B ratio (Caldarone, 2009)

\begin{tabular}{lllll}
$\begin{array}{l}\text { Specified } \\
\text { Compressive }\end{array}$ & $<35$ & $35-55$ & $55-80$ & $80-120$ \\
strength, MPa [psi] & {$[5000]$} & {$[5000-8000]$} & {$[8000-11500]$} & {$[11.500-17.500]$} \\
W/B Ratio & $>0.45$ & $0.45-0.35$ & $0.35-0.29$ & $0.29-0.25$ \\
$\begin{array}{l}\text { Chemical admixture \#1 } \\
\text { Chemical admixture \#2 }\end{array}$ & Optional & WRA or HCA & HCA & HCA \\
SCM \#1 & Optional & WRA or HRWR* & HRWR* & HRWR \\
SCM \#2 & Not necessary & Fly ash or GGBS & Fly ash or GGBS & Fly ash or GGBS \\
\hline
\end{tabular}

Table 5: Mix proportions of all mixes

\begin{tabular}{|c|c|c|c|c|c|c|c|c|c|c|c|c|}
\hline Constituent materials ${ }_{\text {DSF12 }}$ & $\begin{array}{l}\text { ASF0 } \\
\text { DSF1 }\end{array}$ & $\begin{array}{l}\text { ASF8 } \\
2 *\end{array}$ & $\begin{array}{l}\text { ASF10 } \\
\text { DSF12 }\end{array}$ & BSF5 & BSF10 & BSF1 & 2 BSF15 & CSF0 & CSF5 & CSF10 & CSF15 & DSF0 \\
\hline $\begin{array}{l}\text { Cement }\left(\mathrm{kg} \mathrm{m}^{-1}\right){ }^{-1} 488 \\
\text { Silica Fume }\left(\mathrm{kg} \mathrm{m}^{-1}\right)\end{array}$ & $\begin{array}{l}488 \\
-\end{array}$ & $\begin{array}{l}488 \\
39.0\end{array}$ & $\begin{array}{l}470.0 \\
48.8\end{array}$ & $\begin{array}{l}450.0 \\
25.0\end{array}$ & $\begin{array}{l}435.6 \\
45.0\end{array}$ & $\begin{array}{l}421.0 \\
59.4\end{array}$ & $\begin{array}{l}510.0 \\
74.0\end{array}$ & & & & $\begin{array}{l}495.0435 .6 \\
77.0-\end{array}$ & $\begin{array}{l}435.6435 .6 \\
59.4 \quad 59.4\end{array}$ \\
\hline Total Binder $\left(\mathrm{kg} \mathrm{m}^{-1}\right)$ & 488.0 & 527.0 & 536.8 & 495.0 & 495.0 & 495.0 & 495.0 & 510.0 & 510.0 & 510.0 & 510.0495 .0 & $495.0 \quad 495.0$ \\
\hline $\begin{array}{ll}\text { Sand }\left(\mathrm{kg} \mathrm{m}^{-1}\right) & 497 \\
\text { Aggregate }\left(\mathrm{kg} \mathrm{m}^{-1}\right) & 1160 \\
\text { Water }\left(\mathrm{kg} \mathrm{m}^{-9}\right) & 205 \\
\text { Superplasticizer }\left(\mathrm{kg} \mathrm{m}^{-1}\right)\end{array}$ & $\begin{array}{l}497 \\
1160 \\
205 \\
4.88\end{array}$ & $\begin{array}{l}497 \\
1160 \\
205 \\
4.88\end{array}$ & $\begin{array}{l}736 \\
1118 \\
198 \\
4.88\end{array}$ & $\begin{array}{l}736 \\
1118 \\
198 \\
9.9\end{array}$ & $\begin{array}{l}736 \\
1118 \\
198 \\
9.9\end{array}$ & $\begin{array}{l}736 \\
1118 \\
198 \\
9.9\end{array}$ & $\begin{array}{l}736 \\
1118 \\
204 \\
9.9\end{array}$ & $\begin{array}{l}736 \\
1118 \\
204 \\
10.2\end{array}$ & $\begin{array}{l}736 \\
1118 \\
204 \\
10.2\end{array}$ & $\begin{array}{l}736 \\
1118 \\
204 \\
10.2\end{array}$ & $\begin{array}{ll}689 & 689 \\
1033 & 1033 \\
171 & 183.2 \\
10.2 & 9.9\end{array}$ & $\begin{array}{ll}689 & 689 \\
1033 & 1033 \\
183.2 & 171 \\
9.9 & 9.9\end{array}$ \\
\hline
\end{tabular}

Note:

* $\quad \underline{\mathrm{ASF} 0}$

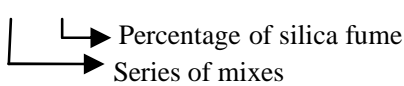

** DSF12* was referred to the mix applied the same mix proportions as DSF12 but original river sand was used instead of modified sand *** DSF12** was referred to the mix applied the same aggregate and binder content as DSF12 but the dosage of superplasticer was increased to $2.5 \%$ and water binder ratio kept at 0.35

There is no further adjustment on the water content as fly ash or ground granulated blast furnace slag is not going to incorporate into the mixture. Hence, the revised water $=171 \mathrm{~kg}$.

From Table 4, the air content was estimated to be $2 \%$. As suggest by Caldarone (2009), $0.5 \%$ reduction is done to the air content as HRWR would use in the mixture. Hence, the revised air content is $1.5 \%$ of the mixture.

Target water/binder ratio: From Table 5, the feasible water-binder ratio was in the range of 0.29-0.35. As incorporation of silica fume would increase the water demand of mixture, W/B ratio of 0.35 was chosen to apply in the mixture.

\section{Estimated binder content, B:}

$\mathrm{B}=171 / 0.35$

$=489 \mathrm{~kg}$
The previous mix with $488 \mathrm{~kg}$ binder content was done. A slightly increase of binder content to $495 \mathrm{~kg}$ has shown a more satisfactory result:

Hence, try B $=495 \mathrm{~kg}$

Fine and coarse aggregate content: The volume of fine aggregate was kept at $40 \%$ from the total aggregate ontent. (Mehta and Aitcin, 1990; Mehta and Monteiro, 2006).

\section{By absolute volume calculation:}

$\begin{aligned} \text { Cement volume } & =495 / 3.15(1000) \\ & =0.157 \mathrm{~m}^{3} \\ \text { Water } & =171 / 1000 \\ \text { Hence, aggregate content } & =1.000-0.015-0.157-0.171 \\ & =0.657 \mathrm{~m}^{3}\end{aligned}$


Am. J. Applied Sci., 7 (12): 1562-1568, 2010

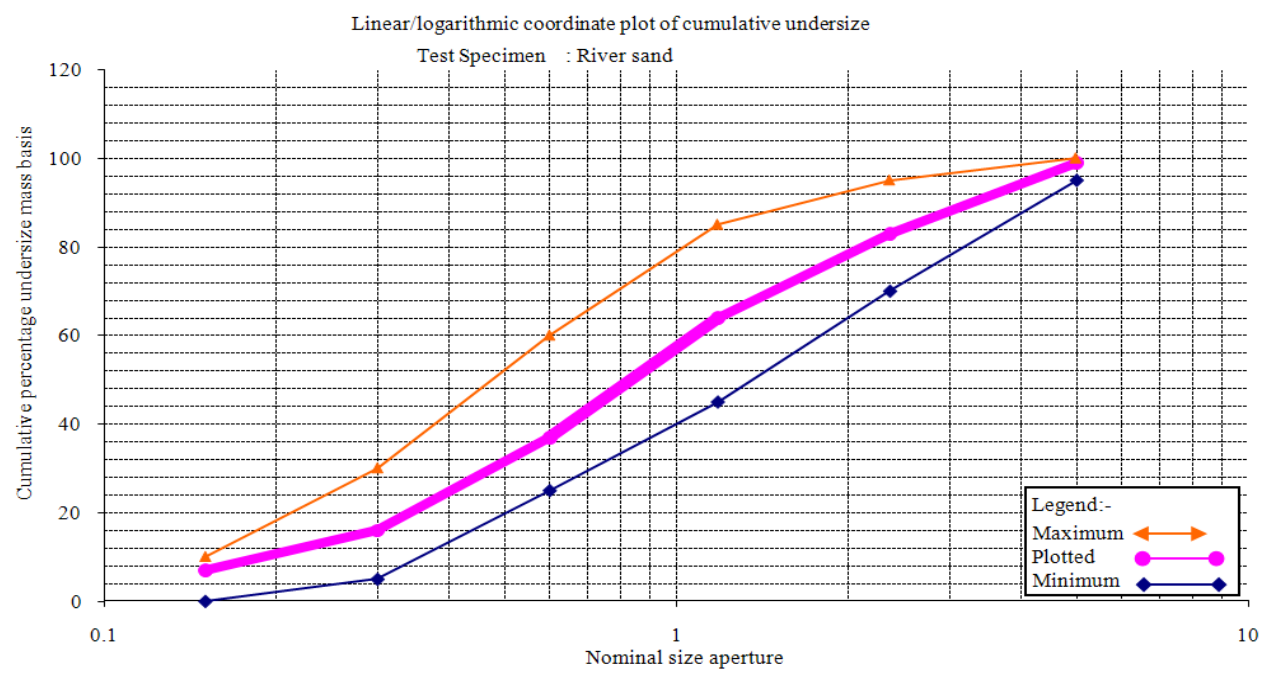

Fig. 1: Particle size distribution of original river sand

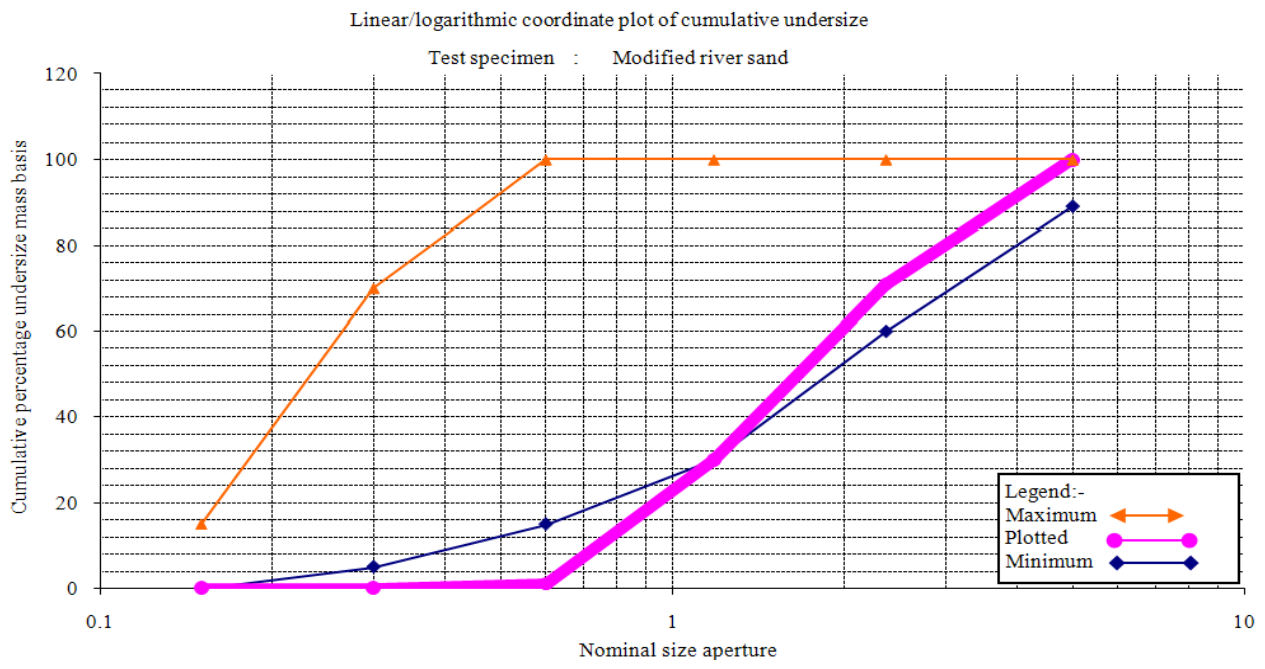

Fig. 2: Particle size distribution of modified river sand
Fine (F) to Coarse (C) Ratio $\quad=\mathbf{2 : 3}$
Specific gravity of fine aggregate $\quad=2.51$
Specific gravity of coarse aggregate $=2.70$

$$
\begin{aligned}
\mathrm{C} & =1033 \\
\mathrm{~F} & =2 / 3(1033) \\
& =689 \mathrm{~kg} .
\end{aligned}
$$

$\mathrm{F}: \mathrm{C}$

$2: 3$

$\mathrm{F}=\frac{2}{3} \mathrm{c}$

Fine aggregate volume + coarse aggregate volume $=0.658$ :

$\frac{2 c}{3 * 2.51 * 1000}+\frac{c}{2.70 * 1000}=0.657$
Final revision after mixing: In order to cast for the specimens with $12 \%$ of silica fume as replacement to total cementitious content, it was found that the minimum water content necessary to particle surfaces was $183 \mathrm{~kg} \mathrm{~m}^{-3}$ so the water/binder content became 0.37 .

\section{RESULTS AND DISCUSSIONS}

The performance of all mixes including consistency, compressive strength and the assessments 
of cement and binder efficiency were presented in Table 6. The evolution of the compressive strength approaching high strength was clearly shown.

The highest compressive strength in both 7 and 28 days was achieved by DSF12, attained 63.2 and 70.6 MPa respectively. Compared to the A series mixes, the compressive strength was increase in two order of magnitudes. From the B series onwards, the using the exactly same materials (same fineness modulus of sand as well), the rational approaches as described in the mix design procedures was drastically increased the compressive strength of concrete in the evolution process. As compared to mixes of ASF10, BSF12and CSF0 which attained the highest compressive strength in each series, the strength obtained by DSF12 was increased by $145,70.4$ and $78.5 \%$ respectively in 7 days and $45.0 \%, 34.7 \%$ and $43.8 \%$ respectively in 28 days. In the D series mixes, it showed an abnormally high development of compressive strength in the first 7 days. Under normal temperature water curing conditions, the 7 days strength was fall in the range of $79.1-89.5 \%$ of 28 days strength. This is relatively high compared to the A, B and C series mixes which showed only 51.7$55.761 .0-70.8 \%$ and $65.8-72.1 \%$ respectively.

Cement and binder efficiency indices: Cement and binder efficiency indices is a ratio of compressive strength possess by concrete to the amount of cement and binder in unit $\mathrm{kg}$ per cubic meter. The indices are a measure of effectiveness of total cement or binder amount use to develop the compressive strength of a concrete (Chang et al., 2001). In this study, the results showed that the incorporation of silica fume was marginally increased the cement efficiency indices of the mixture. In A and D series mixes, the values at 28 days were increased by $33.3 \%$ and $26.6 \%$ compared between the mixes attained highest value and mixes without silica fume in each series respectively. Rational mix design approach employed in the $\mathrm{D}$ series mixes also showed significant improvement as compared to the previous mixes. The highest cement and binder efficiency indices were achieved by the DSF12 trial mixes, $0.162 \mathrm{MPa} \mathrm{kg}^{-1}$ and $0.143 \mathrm{MPa} \mathrm{kg}$ respectively. Compared between the highest and lowest cement efficiency index at 28 days, which is between DSF12 and ASF0 the value was increased by $116 \%$. The highest binder efficiency index at 28 days for the $\mathrm{D}$ series mixes of $0.143 \mathrm{MPa} \mathrm{kg}^{-1}$ was also increased by 57.134 .9 and $49.0 \%$ compared to the highest value in the $\mathrm{A}, \mathrm{B}$ and $\mathrm{C}$ series mixes respectively.

Silica fume as cement replacement: In A series mixes, inclusion of $10 \%$ of silica fume to the mixture was able to increase the compressive strength by $32.3 \%$ as compared to control. Both cement and binder efficiency was also increased 33.3 and $21.3 \%$ respectively at age 28 days. However, results showed that $12 \%$ replacement of total binder content by silica fume in the $\mathrm{B}$ series mixes achieved the highest compressive strength in both 7 and 28 days. This was due to the ultra fines particles allowed better packing of the composite materials and hence densified the interfacial transitions zone. It would then enhance the efficiency of load transfer in the micro structure of hardened concrete. Other than that, the formation of calcium silicate hydrate by silica fume was also helped to improve the performance of concrete (Caldarone, 2009). However, further increase of silica fume replacement level to $15 \%$ adversely affected the compressive strength. The strength was dropped by $10.9 \%$. It might be due to the excessive amount of silica fume resulted incompatibility between the composite materials. The results obtained in B and $\mathrm{C}$ series mixes contributed to the decision to choose $12 \%$ replacement of total cementitious amount by silica fume in the D series mixes. The result obtained was finally $8.6 \%$ greater than the target strength (65 MPa).

Table 6: Average test results of all trial mixes of concrete

\begin{tabular}{|c|c|c|c|c|c|c|c|c|c|c|c|c|c|c|c|}
\hline \multirow[b]{3}{*}{ Slump (mm) } & $\begin{array}{l}\text { ASF0 } \\
\text { DSF12 }\end{array}$ & ASF8 & ASF10 & BSF5 & BSF10 & BSF12 & BSF15 & CSF0 & CSF5 & CSF10 & CSF15 & DSF0 & DSF12 & \multicolumn{2}{|c|}{ DSF12* } \\
\hline & & & & & & & & & & & & & & & \\
\hline & 170 & 30 & 10 & 25 & 18 & 16 & 10 & 35 & 28 & 18 & 9 & 65 & 25 & 88 & 120 \\
\hline \multicolumn{16}{|c|}{ Compressive strength (MPa) } \\
\hline 7 days & 20.5 & 22.2 & 25.8 & 30.7 & 30.7 & 37.1 & 32.4 & 35.4 & 28.0 & 31.1 & 31.3 & 54.1 & 63.2 & 48.9 & 59.3 \\
\hline 28 days & 36.8 & 42.9 & 48.7 & 48.3 & 50.3 & 52.4 & 46.7 & 49.1 & 39.6 & 44.3 & 47.6 & 63.5 & 70.6 & 61.8 & 66.3 \\
\hline \multicolumn{16}{|c|}{ Cement efficiency $\left(\mathrm{Mpa} \mathrm{kg}^{-1}\right)$} \\
\hline 7 days & 0.042 & 0.045 & 0.053 & 0.065 & 0.068 & 0.085 & 0.077 & 0.069 & 0.058 & 0.068 & 0.072 & 0.109 & 0.145 & 0.112 & 0.136 \\
\hline 28 days & 0.075 & 0.088 & 0.100 & 0.103 & 0.112 & 0.120 & 0.111 & 0.096 & 0.082 & 0.097 & 0.110 & 0.128 & 0.162 & 0.142 & 0.152 \\
\hline \multicolumn{16}{|c|}{ Binder efficiency $\left(\mathrm{Mpa} \mathrm{kg}^{-1}\right)$} \\
\hline 7 days & 0.042 & 0.042 & 0.048 & 0.062 & 0.062 & 0.075 & 0.065 & 0.069 & 0.055 & 0.061 & 0.061 & 0.109 & 0.128 & 0.099 & 0.120 \\
\hline 28 days & 0.075 & 0.081 & 0.091 & 0.098 & 0.102 & 0.106 & 0.097 & 0.096 & 0.078 & 0.087 & 0.093 & 0.128 & 0.143 & 0.125 & 0.134 \\
\hline
\end{tabular}


Consistency of concrete: The consistency of the concrete is access by the measure of slump in this study. For every series mixes, the slump was reduced drastically with the incorporation of silica fume. The higher the amount of silica fume, the lower the slump achieved by concrete. This is due to the relatively large surface of micro silica particles needed a lot more water to surface of particles to perform hydration process. The increased in superplasticer dosage from 2.0-2.5\% by weight of binder in the DSF12** has increased the slump drastically even thought the water cement ratio was reduced from $0.37-0.35$. In addition, the reduced in fineness modulus of sand as proved by DSF12* was also able to increase the slump of the mixes.

Increase of total cementitious amount: The results for the $\mathrm{B}$ and $\mathrm{C}$ series mixes were able to illustrate the effects of increase in total binder content to the performance of the mixes. It displayed that the increase in total cementitous amount in the mixture proportions has negative effects on the compressive strength of concrete. The highest compressive strength was reduced by $6.3 \%$. For the same replacement percentage, 5 and $10 \%$ both showed a decrease value, by 18.0 and $11.9 \%$ respectively at 28 days strength. However, for the $15 \%$ replacement, the compressive strength value slightly increased by $1.9 \%$, which is insignificant compared to the drop value. Due to economic effect, higher dosage of silica fume is also not advisable.

Fineness modulus of fine aggregates: The fineness modulus is the sum of accumulate percentage retained on specific sieves divide by 100 (Legg, 1998). The river sand was modified by the elimination of undersize of 600 micron particles, attained fineness modulus 3.98. This modification has resulted the silt and clay content reduced to $0.17 \%$. These factors were partly responsible to the better strength development of concrete. A drastically change in the 7 days compressive strength to the mixes using this modified river sand as fine aggregate. The highest 7 and 28 days compressive strength attained by the A series mixes using original river sand was increased by 145 and $45 \%$ respectively compared to the DSF12 which casted using modified river sand as fine aggregate. The different between mixes DSF12 and DSF12* was only the fineness modulus of sand used in the mixture. DSF12* was prepared with the original river sand (fineness modulus = 2.94). The compressive strength showed by DSF12 was 29.2 and $14.2 \%$ higher than DSF2* in 7 and 28 days respectively. Other than that, the higher fineness modulus of fine aggregate has also resulted higher strength gain in 7 days. The ratio of compressive strength at 7 days over 28 days for DSF12 and DSF12* was 89.5 and $79.1 \%$ respectively. It was differed about $10 \%$. Furthermore, the statistical results in B and C series was also showed higher strength gain in 7 days compared to A series mixes.

Mixture proportioning of concrete: From B-D series mixes, the statistical average results showed significant changing in compressive strength achievements of concrete. This changing was due to mixture proportioning of concrete as specimens were prepared by the same constituent materials. The mix proportions of $\mathrm{B}$ series mixes was simulated according to the literature showing to have compressive strength of 111 MPa at 28 days and slump 230mm. (Neville, 1995). However, during mixing process, it was found that the minimum water content required to wet the entire surface of particles was $198 \mathrm{~kg} / \mathrm{m}^{3}$ instead of $143 \mathrm{~kg} / \mathrm{m}^{3}$ as shown in literature. The alteration in water content and other deviations of properties of constituent materials changed the entire properties of concrete as compared to literature. The total weight of constituent materials of $B$ and $C$ series mixes was $2557 \mathrm{~kg} \mathrm{~m}^{-3}$ and $2578 \mathrm{~kg} / \mathrm{m}^{3}$ respectively. This density was unable to achieve by the normal weight constituents materials in hardened concrete. In addition, the absolute volume of both series was in the range of 1.066-1.073 and 1.067 to 1.084 respectively varied with the silica fume content. There is in no way the absolute volume can exceed 1.0. For $\mathrm{D}$ series mixes, it was designed properly by referring to the specific methods. The total density was between $2398 \mathrm{~kg} \mathrm{~m}^{-3}-2410 \mathrm{kgm}^{-3}$ and the absolute volume was between 0.98-0.99. The fineness modulus of sand, incorporation of silica fume and superplasticizer, optimum fine to coarse ratio in order to obtain minimum percent of voids and lowest possible of water binder ratio to obtained desired slump have been considered in the design mix process. Therefore, the highest compressive strength was obtained.

\section{CONCLUSION}

From the experimental investigations, several conclusions as follow can be drawn:

- A high strength concrete attaining compressive strength $70.6 \mathrm{MPa}$ at 28 days and high early strength development at the first 7 days of 63.2 MPa can be produced using the mixture proportioning method as described above

- Increasing fineness modulus of fine aggregates, minimizing clay and silt content in sandand 
incorporation of silica fume showed very encouraging effects in compressive strength

- Incorporation of silica fume has increased the water demand drastically or adversely affected the consistency of the mixture

- The mix design of concrete showed in literatures was difficult to achieve due to the deviations in constituent materials, especially from different geographical status

- By applying same constituent materials, specific mixture proportioning method enabled the high strength achievement with high cement and binder efficiency indices

\section{ACKNOWLEDGEMENT}

The authors were sincerely appreciated and thanks to the Fellowship of University Sains Malaysia and grant USM-RU-PGRS Grant No. 1001/PPBGN/843058 for its financial supports for this study.

\section{REFERENCES}

Ravichandran, A., K. Suguna and P.N. Ragunath, 2009. Strength modeling of high-strength concrete with hybrid fibre reinforcement. Am. J. Applied Sci., 6: 219-223. DOI: 10.3844/ajassp.2009.219.223

Roshan, A.M.G., M.B. Hosseinian, H. Khalilpasha and R. Amirpour, 2010. Optimization of micro silica in light weight lika concrete. Am. J. Engineer. Applied Sci., 3: 449-453. DOI: 10.3844/ajeassp.2010.449.453

American Concrete Institute, 2007. ACI 211.191(R2002): Standard practice for selecting proportions for normal, heavyweight and mass concrete. http://www.techstreet.com/cgi-bin/detail?

American Concrete Institute, 2007. ACI 318-08: building code requirements for structural concrete and commentary. http://www.techstreet.com/standards/ACI/318_08? product_id=1736646
Alves, M., R. Cremonini and D.D Molin, 2004. A comparison of mix proportioning methods for high-strength concrete. Cement Concrete Composites, 26: 613-621. DOI: 10.1016/S09589465(03)00036-2

BS EN 12350-2, 2009. Testing fresh concrete. Slumptest. https: //bsol.bsigroup.com/en/Bsol-ItemDetail-Page/?pid=000000000030164882

BS EN 12390-3, 2009. Testing hardened concrete. https://bsol.bsigroup.com/en/Bsol-Item-DetailPage/?pid=000000000030164906

Caldarone, M.A., 2009. High-Strength Concrete a Practical Guide. 1st Edn., Taylor and Francis, US and Canada, pp: 1-119. ISBN: 0-203-96249-4

Chang, T.P., S.H. Lin, H.C. Lin and P.R. Lin, 2001. Effects of various fineness moduli of fine aggregate on engineering properties of high-performance concrete. J. Chinese Ins. Eng., 24: 289-300. http://www.crt.ntust.edu.tw/jcie/pdf/24-3PDF/289-300.PDF

Legg, F.E.J., 1998. Aggregates. In: Concrete Construction Handbook. Dobrowolski, J.Q. (Ed.). Unitted States of America: McGraw-Hill Companies, pp: 2.1-2.58. ISBN: 0-07-017198-X

Khatri, R. and V. Sirivivatnanon, 1995. Effect of different supplementary cementitious materials on mechanical properties of high performance concrete. Cement Concrete Res., 25: 209-220. DOI: $10.1016 / 0008-8846(94) 00128-\mathrm{L}$

Mehta, P.K. and P.J. Monteiro, 2006. Concrete Microstructure, Properties and Materials. 3rd Edn., The McGraw-Hill Companies, United States of America, pp: 659. ISBN: 0071462899

Mehta, P.K. and P.C. Aitcin, 1990. Principles underlying production of high-performance concrete. Cement, Concrete, Aggregates, 12: 70-78. DOI: $10.1520 / C C A 10274 J$

Naidu, K.G., 1995. The petronas tower: The world's tallest building. http://www.jtkconsult.com.my/pdf/CPAC95.pdf

Neville, A.M., 1995. Properties of Concrete. 4th Edn., Harlow: Longman Group Limited, pp: 844. ISBN: 10: 0582230705 